\title{
MODELLING OF A PROCESS, WHICH CAUSES ADHESIVE SEIZING (TACKING) IN PRECISE PAIRS OF HYDRAULIC CONTROL DEVICES
}

\section{MODELOWANIE PROCESU WYWOŁUJĄCEGO ZACIERANIE ADHEZYJNE (SCZEPIANIE) W PARACH PRECYZYJNYCH HYDRAULICZNYCH URZĄDZEŃ REGULACYJNYCH*}

\begin{abstract}
Lack of complete knowledge in the scope of the impact of operating conditions of precise pairs of hydraulic units on the character of the destructive processes arising in them, results in not taking these conditions into account at the early stages of design and manufacturing. One of such little described issues are factors causing adhesive seizing (tacking), created during the process of interaction between slider surfaces of pairs of hydraulic control devices under contact-vibration load. The articles presents general characteristics and mechanisms causing adhesive seizing (tacking) in precise pairs of hydraulic control devices under contactvibration load. It also presents a model describing the process, which causes adhesive seizing (tacking) in a slider hydraulic pair under contact-vibration load. The model allows to carry out both, qualitative, as well as quantitative analysis of the impact of vibration and load parameters on the occurrence of adhesive seizing (tacking) in slider pairs of hydraulic control devices. Practical application of the model requires the determination of the values of coefficients, which characterise the intensity of restoration and seizing resistance of metal oxides on cooperating surfaces of a hydraulic pair. An empirical method for estimating coefficients of the model and an example of estimating model coefficients for a pressure increase limiter were presented.
\end{abstract}

Keywords: aviation, hydraulic drive, hydraulic precise pair, adhesive seizing, tacking

\begin{abstract}
Brak petnej wiedzy w zakresie wptywu warunków pracy par precyzyjnych zespołów hydraulicznych na charakter powstawania w nich procesów destrukcyjnych powoduje, że na etapach projektowania i wytwarzania nie uwzględnia się tych warunków. Jednym $z$ takich mało opisanych zagadnień sq czynniki wywołujace zacieranie adhezyjne (sczepianie), powstajace w procesie wzajemnego oddziaływania powierzchni suwakowych par hydraulicznych urzadzeń regulacyjnych przy obciązeniu kontaktowo-wibracyjnym. $W$ artykule przedstawiono ogólnq charakterystykę i mechanizmy wywołujące zacieranie adhezyjne (sczepianie) w hydraulicznych parach precyzyjnych urzadzeń regulacyjnych przy obciażeniu kontaktowo-wibracyjnym. Zaprezentowano model opisujacy proces wywotujący zacieranie adhezyjne w suwakowej parze hydraulicznej przy jej obciażeniu kontaktowo - wibracyjnym. Model pozwala przeprowadzić zarówno jakościową, jak i ilościowa analizę wplywu parametrów wibracji i obciażenia na wystapienie zacierania adhezyjnego (sczepiania) w suwakowych parach hydraulicznych urządzeń regulacyjnych. Praktyczne wykorzystanie modelu wymaga określenia wartości wspótczynników charakteryzujących intensywność odtwarzania i opór ścierania tlenków metalu ze wspótpracujących powierzchni pary hydraulicznej. Przedstawiono empiryczna metodę szacowania wspótczynników modelu i przykład szacowania współczynników modelu dla ogranicznika narastania ciśnienia.
\end{abstract}

Stowa kluczowe: lotnictwo, napęd hydrauliczny, hydrauliczna para precyzyjna, zacieranie adhezyjne, sczepianie.

\section{Introduction}

One of the most important tasks in the complex of activities aimed at increasing the use quality of a hydraulic drive are studies concerning the impact of working conditions of hydraulic precise pairs on their wear process, meaning, the durability of a hydraulic drive $[1,6$, $7,8,13,19,20,23,24]$. On the basis of data available in the scientifictechnical literature on the wear processes of precise pairs and hydraulic precise pairs, it can be concluded that the dominating wear process is wear due to oxidation $[1,3,4,5,11,13,14,21]$. The fact that the wear due to oxidation is dominating during operation of a hydraulic precise pair, guarantees low wear intensity of cooperating pair surfaces $[1,4,5,13,14]$. Wear due to oxidation is conditioned mainly on maintaining during operation the load (pressure and sliding velocity) of hydraulic precise pair's elements below the critical value (fig. 1) [21]. Fig. 1 presents the relation the wear and the friction coefficient and the slide velocity for the matching of a hydraulic pair made from
$12 \mathrm{HN} 3 \mathrm{~A}(\mathrm{HRC}=60)$ steel and the EI-928 $(\mathrm{HRC}=60)$ steel $)$ in an environment of ASF-41 hydraulic oil, at a temperature of $293 \mathrm{~K}$ and loads of $\mathrm{P}_{\text {axis }}=100 \mathrm{~N}, 600 \mathrm{~N}, 1400 \mathrm{~N}$. Under overcritical values of the slide velocity, there is a stepwise and rapid quantitative change of the friction coefficient between the surfaces of the hydraulic pair's elements (fig. 1b). After reaching the critical slide velocity the adhesive seizing process is initiated and tacking processes of metal surfaces of the hydraulic pair start to dominate on friction surfaces $[10,12,18$, 21]. Though knowledge about wear mechanisms has significantly developed, we still lack a general image of the impact process under specific conditions of cooperation between elements of a precise pair.

When studying the damageability of correlated metal surfaces in conditions of contact-vibration displacement, usually all attention was paid to the development of fretting-corrosion, i.e., to abrasiveoxidizing processes and not tacking $[3,4,10,11,14]$. It is explained by the fact that during vibration friction and an oxidized contact zone, damages are created in the form of pitting, filled with damage prod-

(*) Tekst artykułu w polskiej wersji językowej dostępny w elektronicznym wydaniu kwartalnika na stronie www.ein.org.pl 

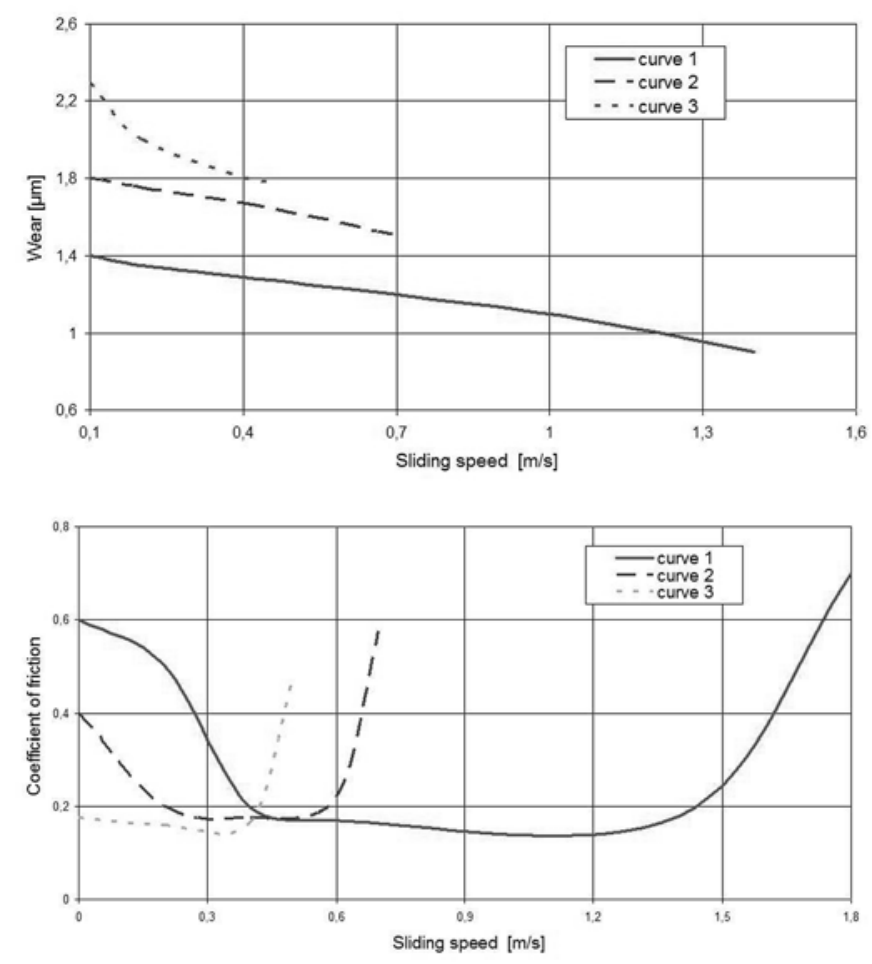

Fig. 1. The dependency of wear (a) and the friction coefficient (b) from the slide velocity of a hydraulic pair made of $12 \mathrm{HN} 3 \mathrm{~A}$ steel and EI-928 steel [21] 1-load $P_{\text {axis }}=100 \mathrm{~N}, 2$-load $P_{\text {axis }}=600 \mathrm{~N}, 3$-load $P_{\text {axis }}=$ $1400 \mathrm{~N}$

ucts, containing mainly of powdered oxides of metals in contact [4, $14,18]$. To develop such a process, relative displacements of touching sections of correlated surfaces, measuring a part of a micrometer. There is a view that in the initial stage of the fretting-corrosion process, there is tacking in micro-section of the surface contact area. Tacking is stopped as the correlated surfaces' wear products accumulate in the contact area $[1,13,15]$. The mentioned papers do not discuss the influence of the ratio of contact surface dimensions and the displacement size of a hydraulic pair's elements, as well as the periodicity of contact breach, on the creation and development of tacking during vibratory slide. That is why the results of such studies, cannot be used to explain causes and regularities of adhesive seizing (tacking) occurrence in hydraulic precise pairs, taking over contact-vibration loads. The distinguishing properties of tacking conditions in hydraulic precise pairs during vibratory slide are the small sizes of relative displacements of correlated surfaces and the load dynamics due to constant changes of the slide velocity.

Identification of factors causing adhesive seizing (tacking) in precise pairs of hydraulic control devices and the model of that phenomenon will allow to carry out both, quantitative and qualitative impact of vibration and load parameters on the occurrence of adhesive seizing (tacking) in slider pairs of hydraulic control devices.

\section{Subject and objective of study}

The data from the operation of aircraft show that a significant amount of damages to the aviation hydraulic drives was caused by adhesive seizing (tacking) of slider pairs of hydraulic control devices [21, 23, 24]. Slider pairs of hydraulic control devices (fig. 2) comprise of perceive and control elements, automatically limiting or changing, acc. to the set pressure, its drop (pressure difference) in connected volumes (surfaces) or the output of the operating fluid. Slider pairs of hydraulic control devices, acc. to the kinetics criterion of their movement and load conditions are characterised by the following features [21]:
- the slider transfers two-sided changeable axial load caused by the operating fluid's pressure and the spring,

- the slider performs a constant reciprocating movement in relation to the cylinder, due to changes of the operating fluid's pressure and the return movement of the spring,

- relative slide velocity of the slider in relation to the cylinder and its acceleration depend on the value of the operating fluid's output reaching the hydraulic pair, the spring's stiffness and the slider mass,

- the slider is tilted under the impact of ever-present eccentricity of the resultants of the operating fluid's forces and spring applied to the slider

- The slider vibrates in the axial direction, as a result of pulsation from the operating fluid's pressure.

Therefore, slider pairs of hydraulic control devices operate only in sliding conditions, under contact-vibration load, taking over only axial loads.

The cylindrical slider is usually tilted under the impact of everpresent eccentricity of the resultants of the operating fluid's forces and spring applied to the slider. Moreover, tilting or one-sided radial pressing of the slider to the bushing is caused by the radial force created as a result of loss of stability of the slider hydraulic pair's spring. As a result of the tilting of the slider in the bushing, the operating fluid's force and the axial component of the spring force create a pair. The size of the torque depends on the size of the backlash in the slider pair and the backlash between the slider head and the spring.
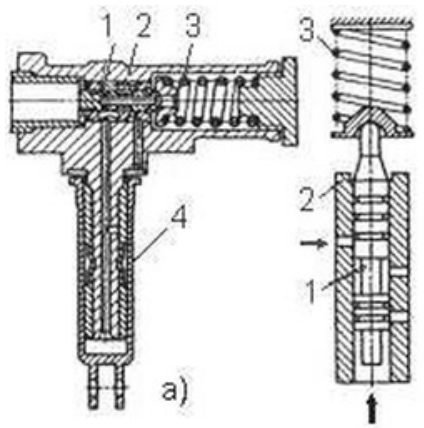

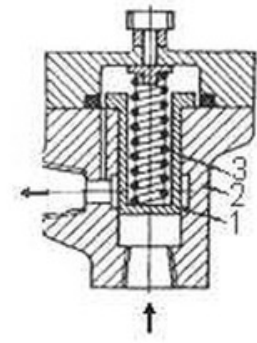

b)

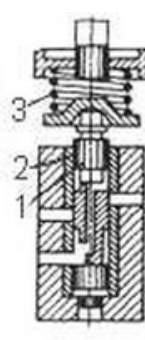

c)
Fig. 2. Diagrams of control slider pairs: proportional valve (a), constant pressure valve (b), pressure relief valve (c) and pressure increase limiter (d)1-Slider; 2-bushing (body); 3-spring; 4-performance controller body

In the operation process, the elements of hydraulic slider pairs of control devices, constantly or periodically, as a result of the changing pressure of the operating fluid, perform relative reciprocating movements at different frequency and amplitude $[2,6,7,8,9,17,19,20]$. At the same time, the movement frequency and amplitude depend on the character of the pressure change (pulsation) of the operating fluid and change, depending on the operating range of the control unit. The slider movement amplitude depends on the size of the operating flu-

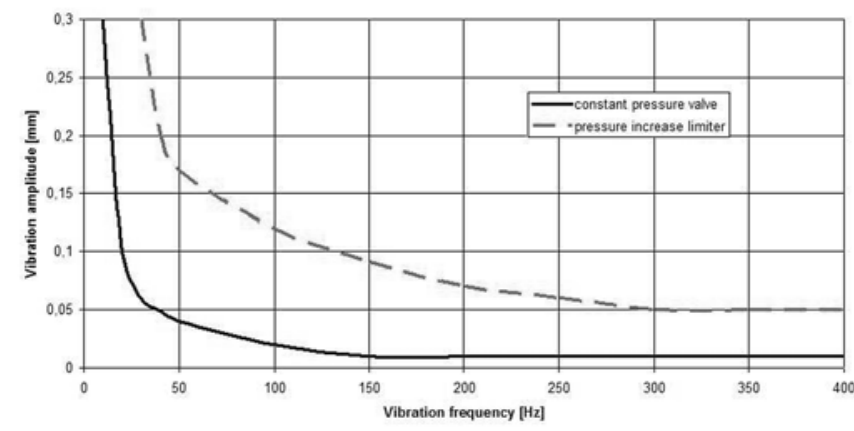

Fig. 3. Range of vibration parameters, with corresponding operating conditions of control slider pairs 
id's pressure change and the spring stiffness $[2,9,11]$. In the case of the pressure pulsation frequency and the own frequency of the slider with the spring overlapping, resonant vibrations may occur $[19,20]$. In certain operating ranges, the slider of a control device may have a complex character of vibratory displacements. Experimental testing showed that the size of the slider's displacement amplitude changes depending on the frequency $[20,22]$. Along with the increase of displacement frequency from $30 \mathrm{~Hz}$ to $500 \mathrm{~Hz}$, the amplitude increases accordingly, from $0.3 \mathrm{~mm}$ to $0.005 \mathrm{~mm}$ (fig. 3) [21].

The aim of the study if to present and discuss the factors which cause adhesive seizing (tacking) in precise pairs of hydraulic control devices and to present a model of this phenomenon. The model should enable quantitative and qualitative analysis of the impact of vibration and load parameters on the occurrence of adhesive seizing (tacking) in precise hydraulic pairs.

\section{Adhesive seizing in slider pairs of hydraulic control devices under contact-vibration load}

By adhesive seizing in hydraulic slider pairs of control devices we will understand a self-fading tacking process, occurring on separate, local, quasi-stationary points of contacts of elements of a working pair in conditions of a vibratory slide, without a temperature increase in the top-layer of metal [14, 21].

Tests of slider pairs of hydraulic control devices showed that their adhesive seizing (tacking) is facilitated by: tilting of a cylindrical slider of a hydraulic pair under the influence of the ever-present eccentricity of the resultants of the operating fluid's forces and spring applied to the slider, as well as constant or periodic relative reciprocating movements of the pair's elements at different frequency and amplitude [13, 19, 21, 22]. The distinguishing properties of adhesive seizing in slider pairs of hydraulic control devices at contact-vibration load are the small sizes of relative displacements of correlated surfaces of the slider pair, the size of the slide velocity and the formation speed of metal oxide layers on cooperating surfaces of the hydraulic pair, as well as the speed of their abrasion.

In order to determine the most favourable vibration ranges, in terms of adhesive seizing (tacking) occurring on cooperating surfaces of a slider pair, experiments were conducted on a vibration stand, which imitates the vibratory movement character of the pair's elements, under the influence of the operating fluid's pressure pulsation. The diagram of the stand is presented in fig. 4.

A precise pair is fastened to a device, which allows to carry out slider movements due to vibrations of the vibration plate. ASF-41 hydraulic oil is inserted in the slider pair surface. An immobile hydraulic pair slider (7 fig. 4) is inserted freely into a bushing (6) of the central opening in the device's body (8). Elastic ring (4) keeps the bushing in the axial direction. At the same time, it is the perceive element when measuring the friction force in a hydraulic pair. With its central part, the ring (4) is put on the bushing head (6) and pressed along the perimeter by the valve body flange (1) to the body of the device. The necks connecting the central and external part of the ring (4) have stuck tensometric sensors (9), which react to deformations of the necks, when the bushing tends to move upwards. Because a bushing can move in the axial direction only under the action of the slider's friction force, the sensor in the testing process register the friction in the hydraulic pair. Longitudinal vibratory displacements are transferred to the slider (7) through a stem (10), fastened on the vibration plate (11) of the stand. An operating spring of the control elements acts on the slider from the top, through a locking plate, with a spherical contact surface. Depending on the needs (requirements), the spring compression degree (effect of loss of stability affecting the spring's slider) may be changed in the course of the test process.

The slider pair of a pressure controller tests were carried out on the above mentioned vibration stand. Average test length was $15 \mathrm{~min}$.

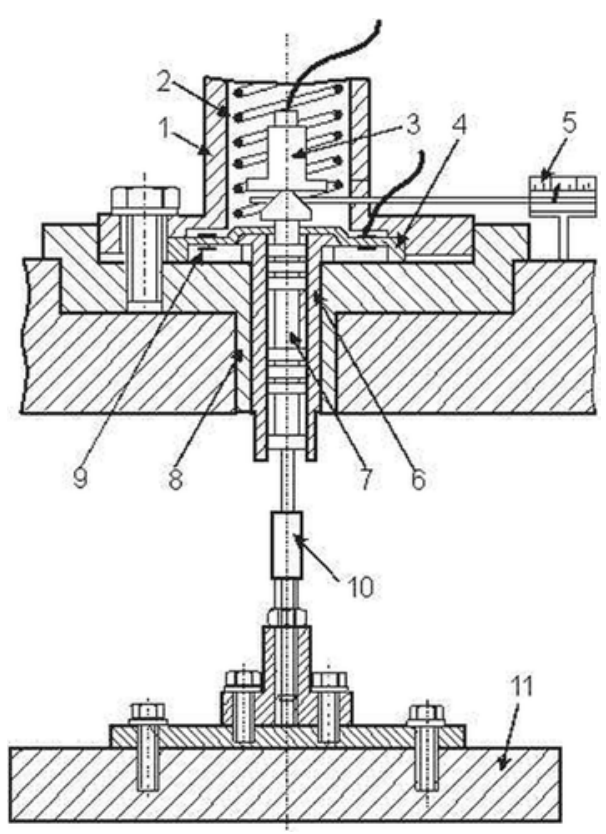

Fig. 4. Diagram of a stand imitating the vibratory displacement character of the slider hydraulic pair's elements under the influence of the operating fluid's pressure pulsation 1) valve body, 2) spring, 3) vibration sensor, 4) elastic ring, 5) force sensor, 6) hydraulic pair bushing, 7) hydraulic pair slider, 8) device body, 9) tensometric sensor, 10) stem of the vibration plate with a vibration sensor, 11) plate of the vibration device

The slider of the controller was axially pressed with the force of a pressure spring with values $50-100 \mathrm{~N}$ and laterally, with a force of $25-50 \mathrm{~N}$. The results of experimental tests of a control device's slider pair on a vibration stand in an ASF-41 oil environment, are presented in table 1.

On the basis of experiments, it was found that the most favourable, in terms of tacking occurring, is the vibration scope in the amplitude range of $0.005-0.1 \mathrm{~mm}$. In this amplitude range, during the tests, slider pair's surface tacking was stably imaged. At amplitudes below $0.005 \mathrm{~mm}$, damages caused by tacking, in many cases were poorly exposed, usually due to their small size. Marks on slider surfaces, appearing at amplitudes greater than $0.1 \mathrm{~mm}$, in most cases were characteristic for intensive oxidation wear of metal surfaces. It was also agreed that radial load of sliders, necessary for tacking elements of a slider pair, increases with the increase of the amplitude. At an amplitude of $0.01 \mathrm{~mm}$, loads applied to the slider during tacking are, on average, $30 \mathrm{~N}$, while at an amplitude of $0.05 \mathrm{~mm}$ are within a range of $40-50 \mathrm{~N}$.

Simultaneously to the sliding of a slider hydraulic pair's elements being in contact, the abrasion and formation processes of metal oxides happen at the same time. At a defined relation between the intensity of load processes and abrasion/restoration of metal oxides on cooperating surfaces of a slider pair, it is possible to create clear surfaces without a layer of metal oxides (clear surfaces) Formation of clear surfaces is only possible with a defined correlation of damage and restoration velocities of oxides and oil membranes absorbed on the surface. When the formation speed of metal oxides layers on cooperating surface of a hydraulic pair is greater than the speed of abrasion from the surface, wear by oxidation occurs; when the formation speed of metal oxides layers on cooperating surface of a hydraulic pair is smaller than the speed of abrasion from the surface, the adhesive seizing (tacking) process begins. The size of surfaces without metal oxides (clear surfaces) depends on the degree of delay of the process of oxide formation (oxidation reaction), i.e., from the time of abrasion of the metal oxide layer until they are recreated on the clear surfaces (increase of the metal oxide layer) $[9,16,18]$. 
Table 1. Result of experimental testing of a pressure adjuster on a station imitating the vibratory displacement character of a hydraulic pair's elements

\begin{tabular}{||c|c|}
\hline $\begin{array}{c}\text { Vibration range } \\
{[\mathrm{mm}]}\end{array}$ & Wear character \\
\hline$<0.005$ & Tacking poorly exposed, (small dimensions). \\
\hline $0.005-0.1$ & $\begin{array}{c}\text { Stable representation of the tacking of the slider pair's surface. } \\
\text { At an amplitude of } 0.01 \mathrm{~mm} \text { - tacking at a load of approx. 30N. } \\
\text { At an amplitude of } 0.05 \mathrm{~mm} \text { - tacking at a load of approx. 40-50N. }\end{array}$ \\
\hline$>0.1$ & Marks characteristic for intensive oxidation wear of metal surfaces. \\
\hline
\end{tabular}

From a theoretical point of view, the increase of loads (pressure) at a point of contact should decrease the resistance of a slider hydraulic pair against the occurrence of adhesive seizing (tacking), because the increase of a load, increases the intensity of metal oxide abrasion $[1,4,5,15,16,18]$. Together with the increase of pressure, the metal is activated, which significantly impact the increase of the thickness of formed metal oxides and protective membranes. However, the occurrence of tacking of cooperating surfaces does not so much depend on the thickness as on the surface occupied by metal oxides and protective membranes (surface-active substances) $[15,16,18]$. Increasing the sliding speed, undoubtedly intensifies both, the seizing process, as well as the process of metal oxides' restoration. The slide speed value depends on the size of the displacement amplitude and vibration frequency. However, increasing the slide speed at the cost of the displacement amplitude rising is limited. This limit is defined by the relation of the vibration displacement amplitude to the point of contact area in the direction of relative displacements. Virtually, adhesive seizing (tacking) in a slider hydraulic pair with vibratory slide, shall not occur, if the ratio of the displacement amplitude and the size of the point of contact of the contact surface in the movement direction is not greater than one $[14,15,16]$.

\section{Modelling the process, which causes adhesive seizing (tacking) in a slider hydraulic pair under contact- vibration load}

When describing processes causing adhesive seizing (tacking) on the local point of contact of elements of a slider hydraulic pair with vibratory slide, one needs to consider the delay of the process of forming metal oxides on the uncovered metal surfaces (clear surfaces). The mentioned delay results from the fact that the oxidation process undergoes over time, regardless of the formation speed of metal oxides on clear surfaces. The oxidation process depends on the ability of penetration of the active oxygen contained in the operating fluid to the uncovered metal areas of surfaces of hydraulic pair elements (clear surfaces) $[4,5,15,16,18]$. As a result, the model of the process, which causes adhesive seizing (tacking) in a slider hydraulic pair under contact-vibration load, should contain the delays $t-\tau$.

The formation speed of metal oxides on the friction surface depends on the slide velocity and the size of the surface where they can be formed, i.e., a clear surface, and not from the size of the normal load (pressure) on the friction contact point. Thickness of the forming metal oxides does not impact the protective properties of the friction surface, i.e., any thickness the metal oxides and adsorbed membranes would have, their presence on the contact section prevents tacking. Therefore, the occurrence of adhesive seizing (tacking) depends on the contact area occupied by metal oxides and not on its thickness. Starting with the above findings, a model of the process, which causes adhesive seizing in a slider hydraulic pair under contact-vibration load, can be presented in the form of a diagram, shown in fig. 5 .

The discussed model of the process, which causes adhesive se-

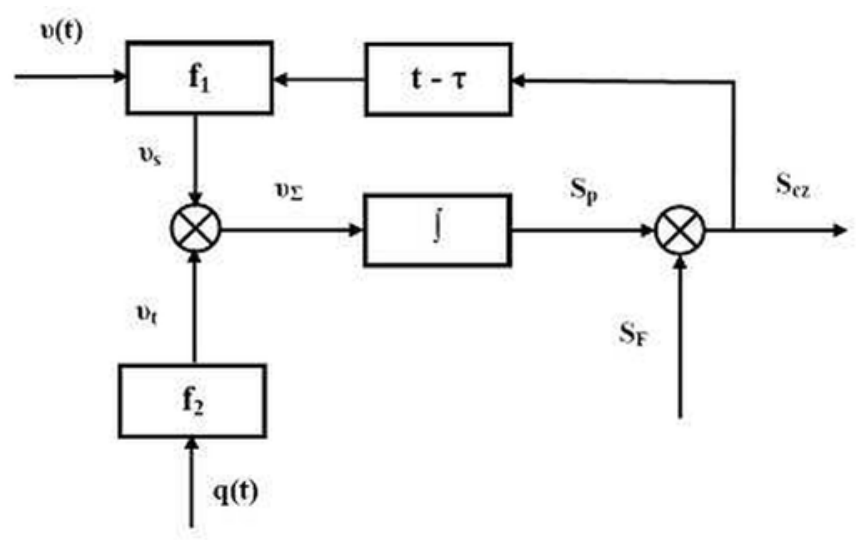

Fig. 5. Diagram of a model of the process, which causes adhesive seizing (tacking) in a slider hydraulic pair under contact-vibration load $f_{1}$ function expressing the dependence of the speed of formation of metal oxides and absorbed membranes from a relevant parameter, $f_{2}$ - function expressing the dependence of the seizing speed of metal oxides and adsorbed membranes from a relevant parameter, $S_{F}$ - surface of the actual contact of hydraulic pair's elements, practically not changing until adhesion (tacking) occurs, $S_{p}$-contact surface coated with metal oxides, $S_{c z}$ - clear surface (no metal oxides on the friction surface), $v_{t}$ -metal oxide seizing speed (decrease of the surface they occupy over a unit of time), $v_{s}$ - metal oxide formation speed (increase of the surface they occupy over a unit of time), $q(t)$ - load parameter, defined with normal load (pressure) values in the contact point of correlated pair surfaces and slide velocity, $v(t)$ - relative slide velocity of correlated surfaces, $\tau$ - time between a clear surface appears and a metal oxide layer forms on these surfaces.

izing (tacking) in a slider hydraulic pair under its contact-vibration load, corresponds to the dependencies:

$$
\begin{gathered}
\frac{d S_{p}}{d t}=v_{s}(t)-v_{t}(t)=v_{\Sigma}(t), \\
v_{s}(t)=f_{1}\left[v(t), S_{c z}(t-\tau)\right], \\
v_{t}(t)=f_{2}[q(t)] S_{c z}(t)=S_{F}-S_{p}(t) .
\end{gathered}
$$

The speed of formation of metal oxides on the friction surface is proportional to the slide velocity and the clear surface (no oxides). The formation speed of metal oxides on the friction surface may be written in the form:

$$
v_{s}(t)=k v(t) S_{c z}(t-\tau)
$$

where: $k$ - coefficient characterising the formation intensity of metal oxides on a clear surface (no oxides) 
Taking into consideration the independence of impact of normal pressure in a contact point of correlated surfaces $p(t)$ and the relative slide velocity of correlated surfaces $v(t)$, the speed of destruction of metal oxides on the friction surface can be described with a relation:

$$
v_{t}[q(t)]=a_{1} v(t)+a_{2} p(t)
$$

where: $a_{1}, a_{2}$ - coefficients characterizing the strength properties of metal oxides,

$p(t)$ - pressure at the contact point of correlated pair surfaces.

Kinetics of seizing off surfaces of hydraulic pair elements and restoration of metal oxides on a clear surface can be described by a differential equation:

$$
\frac{d S_{p}}{d t}+k \cdot v(t) \cdot S_{p}(t-\tau)=v(t)\left(k \cdot S_{F}-a_{1}\right)-a_{2} p(t) .
$$

Expression (6) presents a linear differential equation with a lagging argument. The expression (6) may be written in the general form:

$$
\frac{d S_{p}}{d t}+\Psi(t) S_{p}(t-\tau)=Q(t)
$$

where: $\quad \Psi(t)=k \cdot v(t)$ and $Q(t)=v(t)\left(k \cdot S_{F}-a_{1}\right)-a_{2} p(t)$.

Equation solution (7) has the form:

$$
S_{p}=\left[\int Q(t) e^{\int \Psi(t) d t} d t+C\right] \exp ^{-\int \Psi(t) d t}
$$

The expression analysis (6), shows that:

1) Occurrence of adhesive seizing (tacking) is possible at any impact level of normal pressure in a contact point of correlated surfaces $p$, if the velocity of a relative slide of correlated surfaces $v>0$. However, in actual conditions, it is necessary to consider limiting the normal pressure at point of contact $p>$ $\mathrm{p}_{\mathrm{min}}$, where $\mathrm{p}_{\min }$ is the minimum load (pressure);

2) the time before adhesive seizing (tacking) occurs depends mainly on constants containing the seizing and restoration speeds of metal oxides on a clear surface;

1) in order to solve the differential equation defining the seizing period and the restoration of metal oxides in a seizing point of contact, we need to determine the value of coefficients $k, a_{1}, a_{2}$. These coefficients characterise the intensity of restoration and seizing resistance of metal oxides, as well as the time of emergence of a clear surface and the restoration of a metal oxide layer on this surface. The values of coefficients $k, a_{1}, a_{2}$ can be approximately estimated on the basis of experiments. time $\tau=$ const and that the process of seizing and creating metal oxides undergoes at variable load, i.e., $v(t)=v_{A} \sin \omega t$, where $v_{A}$ is the sliding speed for a given vibration amplitude, we can separate two stages of the process in question. First stage when $0<t \leq \tau$, while the second stage $t>\tau$.

For the first stage, i.e., $0<t \leq \tau$, the equation (6) can be written:

$$
\frac{d S_{p}}{d t}=\left(k S_{c z}(0)-a_{1}\right) \cdot v_{A}|\sin \omega t|-a_{2} p
$$

When $\Psi(t)=k \cdot v(t)=0$ equation (9) takes the form:

$$
\begin{aligned}
& S_{p}=C-\left[k S_{c z}(0)-a_{1}\right] v_{A} \int|\sin \omega t| d t-a_{2} p \int d t= \\
& =C-\left[k S_{c z}(0)-a_{1}\right] \frac{v_{A}}{\omega}[|\cos \omega t|-A(\omega t)]-a_{2} p t
\end{aligned}
$$

where: $C=S_{F}-S_{c z}(0)+\frac{v_{A}}{\omega}\left[k S_{c z}(0)-a_{1}\right]$,

$$
A(\omega t)=\left\{\begin{array}{l}
2|\cos \omega t|, \quad g d y \quad \frac{n \pi}{\omega}<t<\frac{2 n+1}{2} \frac{\pi}{\omega}, \quad n=0,1,2, \ldots . . \\
0, \quad \text { dla innych } t .
\end{array}\right.
$$

A change of the contact surface coated with metal oxides, in the first stage, i.e., $0<t \leq \tau$ can be ultimately expressed in the form of:

$$
S_{p}=S_{F}-S_{c z}(0)+\frac{v_{A}}{\omega}\left[k S_{c z}(0)-a_{1}\right]\{1-[|\cos \omega t|-A(\omega t)]\}-a_{2} p t,
$$

while: $1-[|\cos \omega t|-A(\omega t)] \geq 0$.

The expression (11) indicates that in the first stage, when $0<t \leq \tau$, the surface coated with metal oxides decreases, while the surface without metal oxides increases, while the speed of decreasing of the surface coated with metal oxides, depends on normal pressure at the contact point of correlated surfaces. The decrease of the surface coated with metal oxides is of oscillating character. The oscillation magnitude depends on the change of the slide velocity of correlated surfaces.

For the second stage, i.e., $t>\tau$, the equation (6) can be written:

$$
\frac{d S_{p}}{d t}+k \cdot v_{A}|\sin \omega t| \cdot S_{p}(t-\tau)=v_{A}|\sin \omega t|\left(k \cdot S_{F}-a_{1}\right)-a_{2} p(t)
$$

Equation solution (12) has the form:
Solving a differential equation (6) will allow to determine an order of limit values of the vibration and pressure parameters at the contact point of cooperating surfaces, causing adhesive seizing (tacking) in slider hydraulic pairs.

In the case where we assume (this condition has the greatest practical meaning) that $p=$ const and

$$
\begin{aligned}
& S_{p}=S_{F}-\frac{a_{1}}{k}-a_{2} p e^{\frac{k v_{A}}{\omega}[\cos \omega(t-\tau) \mid-A(\omega(t-\tau))]} \int e^{-\frac{k v_{A}}{\omega}[|\cos \omega(t-\tau)|-A(\omega(t-\tau))]} d(t-\tau)+C e^{\frac{k v_{A}}{\omega}[|\cos \omega(t-\tau)|-A(\omega(t-\tau))]}= \\
& =S_{F}-\frac{a_{1}}{k}-\left[a_{2} p \int e^{-\frac{k v_{A}}{\omega}[|\cos \omega(t-\tau)|-A(\omega(t-\tau))]} d(t-\tau)-C\right] e^{\frac{k v_{A}}{\omega}[\cos \omega(t-\tau) \mid-A(\omega(t-\tau))]}
\end{aligned}
$$


Ultimately, the solution of the equation (12) takes the form:

$$
S_{p}=S_{F}-\frac{a_{1}}{k}-\left[a_{2} p B-C\right] e^{\frac{k v_{A}}{\omega}[|\cos \omega(t-\tau)|-A(\omega(t-\tau))]},
$$

where: $B=\int e^{-\frac{k v_{A}}{\omega}[|\cos \omega(t-\tau)|-A(\omega(t-\tau))]} d(t-\tau)$.

\section{Analytical estimation of the model's $a_{1}, a_{2}, k$ coef- ficients}

In order to solve the differential equation defining the seizing period and the restoration of metal oxides in a friction point of contact (6), we need to determine the value of coefficients $a_{1}, a_{2}, k$.

The volume of metal oxides abraded from the surface of a slide hydraulic pair's element, at pre-set load parameters, can be expressed in the form $V=h \cdot S$, where $h$ is the average thickness of the oxide layers and $S$ is the surface of the correlated contact area.

Assuming that the dependency between the speed of removal of metal oxides from the speed of mutual movement of elements of the hydraulic pair and the contact pressure is linear, we can write that:

$$
d \dot{S}=\frac{\partial \dot{S}}{\partial v} d v+\frac{\partial \dot{S}}{\partial p} d p
$$

where: $\quad \frac{\partial \dot{S}}{\partial v}=a_{1}$ is a coefficient expressing the intensity of removing metal oxides off the surface of a hydraulic pair's element, from the slide velocity,

$\frac{\partial \dot{S}}{\partial p}=a_{2}$ is a coefficient expressing the intensity of removing metal oxides off the surface of a hydraulic pair's element, from the magnitude of the contact pressure.

The volume of metal oxides abraded from the surface of a slider hydraulic pair's element, under pre-set load parameters, can be presented in the form:

$$
d \dot{V}=h \frac{\partial \dot{S}}{\partial v} d v+h \frac{\partial \dot{S}}{\partial p} d p \quad \text { or } \quad d \dot{V}=h a_{1} d v+h a_{2} d p
$$

From the relation (15), we can determine the coefficients $a_{1}$ and $a_{2}$ :

$$
\left\{\begin{array}{l}
a_{1}=\frac{1}{h} \frac{\partial \dot{V}}{\partial v}-a_{2} \frac{\partial p}{\partial v}=\frac{1}{h} \frac{\dot{V}_{2}-\dot{V}_{1}}{v_{2}-v_{1}}-a_{2} \frac{p_{2}-p_{1}}{v_{2}-v_{1}} \\
a_{2}=\frac{1}{h} \frac{\partial \dot{V}}{\partial v}-a_{1} \frac{\partial v}{\partial p}=\frac{1}{h} \frac{\dot{V}_{2}-\dot{V}_{1}}{p_{2}-p_{1}}-a_{1} \frac{v_{2}-v_{1}}{p_{2}-p_{1}}
\end{array}\right.
$$

The $\mathrm{k}$ coefficient, expressing the dependency of the metal oxide forming speed (increase of the occupied surface over a unit of time) from the slide velocity (assuming that $v_{\mathrm{t}}=v_{\mathrm{s}}$ ) can be determined from the relation:

$$
a_{1} v_{1}+a_{2} p_{[r}=k v_{1} S_{c z}
$$

From the relation (17), we determine the $\mathrm{k}$ coefficient, in the form of:

$$
k=\frac{a_{1} v_{1}+a_{2} p_{\Gamma r}}{v_{1} S_{c z}} .
$$

Contact pressure in a slider hydraulic pair, at pre-set load parameters has the form of $p=P / S$, where $\mathrm{P}$ is the load and $\mathrm{S}$ the contact surface. Starting from the above relation, contact pressure can be presented in the form:

$$
p_{[r}=\frac{1}{S_{2}-S_{1}} \int_{S_{1}}^{S_{2}} \frac{P}{S} d S=\frac{P}{S_{2}-S_{1}} \ln \frac{S_{2}}{S_{1}},
$$

where: $S_{1}$ and $S_{2}$ are initial and end contract surface of hydraulic pair's elements.

The volume of metal oxides abraded from the surface of a slider hydraulic pair's element, at pre-set load parameters has the form of $V_{c}=V_{c 2}-V_{c 1}$, where $V_{c 1}$ and $V_{c 2}$ is the volume of metal oxides before and after load. Therefore, the volume of metal oxides abraded off a cylindrical surface of a slider hydraulic pair, under pre-set load parameters, has the form:

$$
V_{c}=\frac{\pi}{192} \frac{d^{4}}{R^{2}}\left(3 R-\frac{d^{2}}{8 R}\right),
$$

where: $d$ is the wear area diameter, while $R$, the replacement radius.

An example for this may be the estimation of coefficients $a_{1}, a_{2}, k$ for the pressure increase limiter, in which the elements of a slider hydraulic pair are made from chrome steel HWG, with a hardness of $\mathrm{HRC}=58$. The pressure increase limiter has the following geometric data: replacement radius $R=6 \mathrm{~mm}$, pitch $l_{A}=0.3 \mathrm{~mm}$.

\section{Estimation example of the $a_{2}$ coefficient}

For the frequency of $f=60 \mathrm{~Hz}$, the slider moving velocity is $v=4 \cdot l_{A} \cdot f=4 \cdot 0,3 \cdot 60=72 \mathrm{~mm} / \mathrm{s}$. The tests on a station imitating the vibratory movement character of elements of the slider hydraulic pair, under operation from the pulsation of the operating fluid's pressure for $P_{l}=14,7 \mathrm{~N}$ and $f=60 \mathrm{~Hz}$ over $\mathrm{t}=30 \mathrm{~min}$, gave the following results:

$$
d_{l}=0.14 \mathrm{~mm}, \quad h_{l}=0.41 \cdot 10^{-3} \mathrm{~mm}, V_{c l}=3.3 \cdot 10^{-6} \mathrm{~mm}^{3} \text {, }
$$$$
d_{2}=0.25 \mathrm{~mm}, h_{2}=1.32 \cdot 10^{-3} \mathrm{~mm}, V_{c l}=31.8 \cdot 10^{-6} \mathrm{~mm}^{3} \text {, }
$$

and for $P_{2}=98.1 \mathrm{~N}$

$$
\begin{aligned}
& \mathrm{d}_{1}=0.25 \mathrm{~mm}, \mathrm{~h}_{1}=1.32 \cdot 10^{-3} \mathrm{~mm}, \mathrm{~V}_{\mathrm{cl}}=31.8 \cdot 10^{-6} \mathrm{~mm}^{3}, \\
& \mathrm{~d}_{2}=0.41 \mathrm{~mm}, \mathrm{~h}_{2}=3.79 \cdot 10^{-3} \mathrm{~mm}, \mathrm{~V}_{\mathrm{cl}}=256 \cdot 10^{-6} \mathrm{~mm}^{3},
\end{aligned}
$$

Volume of metal oxides abraded from the surface of a slider hydraulic pair element for $P_{1}=14.7 \mathrm{~N}$ and $P_{2}=98.1 \mathrm{~N}$ is:

$$
V_{P_{1}}=V_{c 2}-V_{c 1}=(31,8-3,3) \cdot 10^{-6}=28,5 \cdot 10^{-6} \mathrm{~mm}^{3},
$$




$$
V_{P_{2}}=V_{c 2}-V_{c 1}=(256-31,8) \cdot 10^{-6}=224 \cdot 10^{-6} \mathrm{~mm}^{3} .
$$

Wear speed of the volume of $V_{P_{1}}$ and $V_{P_{2}}$ for $P_{1}=14.7 \mathrm{~N}$ and $P_{2}=98.1 \mathrm{~N}$ is:

$$
\begin{gathered}
v_{P_{1}}=\frac{V_{P_{1}}}{t}=\frac{28,5 \cdot 10^{-6}}{1800}=1,6 \cdot 10^{-9} \frac{\mathrm{mm}^{3}}{\mathrm{~s}}, \\
v_{P_{2}}=\frac{V_{P_{2}}}{t}=\frac{224 \cdot 10^{-6}}{1800}=124 \cdot 10^{-9} \frac{\mathrm{mm}^{3}}{\mathrm{~s}} .
\end{gathered}
$$

The initial and end contact area of the hydraulic pair's elements for $P_{1}=14.7 \mathrm{~N}$ and $P_{2}=98.1 \mathrm{~N}$ are:

$S_{1 P_{1}}=\frac{\pi d_{1}^{2}}{4}=\frac{\pi \cdot 0,14^{2}}{4}=0,015 \mathrm{~mm}^{2} ; S_{2 P_{1}}=\frac{\pi d_{2}^{2}}{4}=\frac{\pi \cdot 0,25^{2}}{4}=0,049 \mathrm{~mm}^{2} ;$

$S_{1 P_{2}}=\frac{\pi d_{1}^{2}}{4}=\frac{\pi \cdot 0,26^{2}}{4}=0,053 \mathrm{~mm}^{2} ; S_{2 P_{2}}=\frac{\pi d_{2}^{2}}{4}=\frac{\pi \cdot 0,41^{2}}{4}=0,132 \mathrm{~mm}^{2} ;$

Average contact pressure for $P_{1}=14.7 \mathrm{~N}$ and $P_{2}=98.1 \mathrm{~N}$ is:

$$
\begin{aligned}
& p_{[r 1}=\frac{P_{1}}{S_{2 P_{1}}-S_{1 P_{1}}} \ln \frac{S_{2 P_{1}}}{S_{1 P_{1}}}=\frac{14,7}{0,049-0,015} \ln \frac{0,049}{0,015}=512 \frac{\mathrm{N}}{\mathrm{mm}^{2}}, \\
& p_{[r 2}=\frac{P_{2}}{S_{2 P}-S_{1 P_{2}}} \ln \frac{S_{2 P_{2}}}{S_{1 P_{2}}}=\frac{98,1}{0,132-0,053} \ln \frac{0,132}{0,053}=1133 \frac{\mathrm{N}}{\mathrm{mm}^{2}} .
\end{aligned}
$$

The $a_{2}$ coefficient is:

$$
a_{2}=\frac{1}{h} \frac{v_{P_{2}}-v_{P_{1}}}{p_{[r 2}-p_{[r 1}}=\frac{1}{25 \cdot 10^{-6}} \frac{(124-1,6) \cdot 10^{-9}}{1133-512}=0,19 \cdot 10^{-3} \frac{\mathrm{mm}^{4}}{\mathrm{~N} \cdot \mathrm{s}}
$$

\section{Estimation example of the $a_{1}$ coefficient}

For the frequency $f_{1}=20 \mathrm{~Hz} v_{1}=4 \cdot l_{A} \cdot f_{1}=4 \cdot 0,3 \cdot 20=24 \mathrm{~mm} / \mathrm{s}$ and for the frequency $f_{2}=60 \mathrm{~Hz} v_{2}=4 \cdot l_{A} \cdot f_{2}=4 \cdot 0,3 \cdot 60=72 \mathrm{~mm} / \mathrm{s}$. From the studies for $P_{1}=14.7 \mathrm{~N}$ and $v_{1}=24 \mathrm{~mm} / \mathrm{s}$ the following was obtained:

$$
\begin{aligned}
& \mathrm{d}_{1}=0.14 \mathrm{~mm}, \quad \mathrm{~h}_{l}=0.41 \cdot 10^{-3} \mathrm{~mm}, \mathrm{~V}_{c l}=3.3 \cdot 10^{-6} \mathrm{~mm}^{3}, \\
& \mathrm{~d}_{2}=0.18 \mathrm{~mm}, \quad \mathrm{~h}_{2}=0.83 \cdot 10^{-3} \mathrm{~mm}, \mathrm{~V}_{c l}=12.9 \cdot 10^{-6} \mathrm{~mm}^{3} .
\end{aligned}
$$

From the studies for $P_{1}=14.7 \mathrm{~N}$ and $v_{2}=72 \mathrm{~mm} / \mathrm{s}$ the following was obtained:

$$
\begin{aligned}
& d_{1}=0.14 \mathrm{~mm}, \quad h_{1}=0.41 \cdot 10^{-3} \mathrm{~mm}, V_{c l}=3.3 \cdot 10^{-6} \mathrm{~mm}^{3}, \\
& d_{2}=0.25 \mathrm{~mm}, \quad h_{2}=1.32 \cdot 10^{-3} \mathrm{~mm}, V_{c l}=31.8 \cdot 10^{-6} \mathrm{~mm}^{3} .
\end{aligned}
$$

Volume of metal oxides abraded from the surface of a slider hydraulic pair element for $v_{1}=24 \mathrm{~mm} / \mathrm{s}$ and $v_{2}=72$ is:

$$
V_{v_{1}}=V_{c 2}-V_{c 1}=(12,9-3,3) \cdot 10^{-6}=9,6 \cdot 10^{-6} \mathrm{~mm}^{3},
$$

$$
V_{v_{2}}=V_{c 2}-V_{c 1}=(31,8-3,3) \cdot 10^{-6}=28,5 \cdot 10^{-6} \mathrm{~mm}^{3} .
$$

Wear speed of the volume of $V_{v_{1}}$ and $V_{v_{2}}$ for $P_{l}=14.7 \mathrm{~N}$ is:

$v_{1 v_{1}}=\frac{V_{v_{1}}}{t}=\frac{9,6 \cdot 10^{-6}}{1800}=5,3 \cdot 10^{-9} \frac{\mathrm{mm}^{3}}{\mathrm{~s}}, v_{2 v_{2}}=\frac{V_{P_{2}}}{t}=\frac{28,5 \cdot 10^{-6}}{1800}=15,8 \cdot 10^{-9} \frac{\mathrm{mm}^{3}}{\mathrm{~s}}$.

The initial and end contact area of the hydraulic pair's elements for $v_{1}=24 \mathrm{~mm} / \mathrm{s}$ and $v_{2}=72$ are:

$$
S_{1}=\frac{\pi\left(d_{2}-d_{1}\right)^{2}}{4}=\frac{\pi \cdot(0,18-0,14)^{2}}{4}=0,016 \mathrm{~mm}^{2} \text {; }
$$

$$
\begin{aligned}
& S_{2 v_{1}}=\frac{\pi d_{1}^{2}}{4}=\frac{\pi \cdot 0,18^{2}}{4}=0,025 \mathrm{~mm}^{2} \\
& S_{2 v_{2}}=\frac{\pi d_{2}^{2}}{4}=\frac{\pi \cdot 0,25^{2}}{4}=0,049 \mathrm{~mm}^{2}
\end{aligned}
$$

Average contact pressure for $v_{1}=24 \mathrm{~mm} / \mathrm{s}$ and $v_{2}=72$ is:

$$
p_{[r 1}=\frac{P_{1}}{S_{2 v_{1}}-S_{1}} \ln \frac{S_{2 v_{1}}}{S_{1}}=\frac{14,7}{0,025-0,016} \ln \frac{0,025}{0,016}=729 \frac{\mathrm{N}}{\mathrm{mm}^{2}},
$$

$$
p_{[r 2}=\frac{P_{1}}{S_{2 v_{2}}-S_{1}} \ln \frac{S_{2 v_{2}}}{S_{1}}=\frac{14,7}{0,049-0,016} \ln \frac{0,049}{0,016}=498 \frac{\mathrm{N}}{\mathrm{mm}^{2}} .
$$

The $a_{l}$ coefficient is:

$$
\begin{aligned}
& a_{1}=\frac{1}{v_{2}-v_{1}}\left[\frac{v_{v_{2}}-v_{v_{1}}}{h}-a_{2}\left(p_{[r 1}-p_{[r 2}\right)\right]= \\
& =\frac{1}{72-24}\left[\frac{(15,8-5,3) \cdot 10^{-9}}{30 \cdot 10^{-6}}-0,24 \cdot 10^{-3}(498-729)\right]=12,7 \cdot 10^{-6} \mathrm{~mm}
\end{aligned}
$$

\section{Estimation example of the $\boldsymbol{k}$ coefficient}

The $k$ coefficient is determined from the relation (18). It needs to be assumed that the clear surface (no metal oxides on the friction surface) $S_{c z}$ is $30 \%$ of the surface of actual contact of hydraulic pair elements $S_{F}$ i.e. $S_{c z}=0.3 S_{F}[14,16]$. The surfaces of actual contact of elements of the hydraulic pair $S_{F}$ are determined from the relation [13]:

$$
S_{F}=\pi\left(\frac{3}{4} \kappa R P\right)^{\frac{2}{3}}
$$

where: $\kappa=\frac{1-v_{1}^{2}}{E_{1}}+\frac{1-v_{2}^{2}}{E_{2}}$ and $E_{1}, E_{2}, v_{1}, v_{2}$ are material and Poisson coefficients. For chrome steel HWG $\kappa=0,858 \cdot 10^{-4} \mathrm{~mm}^{2} / \mathrm{N}$. 
For chrome steel HWG at $R=6 \mathrm{~mm} \mathrm{~S}_{F}=\pi\left(\frac{3}{4} \cdot 0,858 \cdot 10^{-4} \cdot 6 \cdot 98,1\right)^{\frac{2}{3}}=0 \mathrm{~mm}^{2}$.

Clear surface (no metal oxides on friction surface) $S_{c z}=0,3 S_{F}=$ $=0,3 \cdot 0,055=0,0165 \mathrm{~mm}^{2}$.

Coefficient $k=\frac{a_{1} v_{1}+a_{2} p_{\Gamma r}}{v_{1} S_{c z}}=\frac{12,7 \cdot 10^{-6} \cdot 24+0,24 \cdot 10^{-3} \cdot 961}{24 \cdot 0,0165}=0,63 \mathrm{~mm}^{-1}$.

\section{Conclusions}

A prerequisite for the adhesive seizing (tacking) process in a slider pair of a hydraulic control device is its point of contact-vibration load. The main factor creating adhesive seizing (tacking) is the seizing speed, i.e., formation of clear surfaces without a metal oxide layer and the restoration of metal oxides on cooperating surfaces of the slider pair. The seizing and restoration speed of metal oxides on cooperating surfaces of the slider pair depends on the values of the vibration and pressure parameters at the point of contact of cooperating surfaces of the slider pair. Formation of clear surfaces (no metal oxides) is possible only at a defined correlation of seizing and restoration velocities of oxides and oil membranes absorbed on the surface. When the formation speed of metal oxide coatings on cooperating surfaces of the slider hydraulic pair is smaller than the speed of their seizing, the adhesive seizing (tacking) process begins.

The proposed analytic method of describing seizing and restoration of metal oxides at a friction point of contact allows to carry out both, qualitative, as well as quantitative analysis of the impact of vi- bration and load parameters on the occurrence of adhesive seizing (tacking) in slider pairs of hydraulic control devices. In order to solve the differential equation defining the seizing period and the restoration of metal oxides in a seizing point of contact, we need to determine the value of coefficients $k, a_{1}, a_{2}$. These coefficients characterise the intensity of restoration and seizing resistance of metal oxides, as well as the time of emergence of a clear surface and the restoration of a metal oxide layer on this surface. The values of coefficients $k, a_{1}, a_{2}$ can be approximately estimated on the basis of experiments. During the tests, you need to estimate the seizing speed of metal oxides and their restoration on clear surfaces under different values of the slide speed and load (pressure) at the friction contact point and the wear resistance of steel in conditions of limit friction. The impact of the sliding speed and the load can be estimated in the process of testing samples in conditions similar to the conditions of the formation of adhesive seizing (tacking), where there is also oxidizing wear present.

The proposed model of the process, which causes adhesive seizing in a slider hydraulic pair with its vibration load, allows to determine the order of limit values of vibrations and pressure at the point of contact of cooperating surfaces, which, when exceeded, will cause adhesive wear in this pair.

\section{References}

1. Bushan B. Introduction to Tribology. John Wiley \& Sons, New York, 2002.

2. Chenxiao N, Xushe Z. Study on vibration and noise for the hydraulic system of hydraulic hoist. Proceedings of 2012 International Conference on Mechanical Engineering and Material Science. MEM 2012;126-128, http://dx.doi.org/10.2991/mems.2012.95.

3. Choi S H, Jin Y S. Evaluation of stored energy in cold-rolled steels from EBSD data. Materials Science \& Engineering 2004; A371: 149-159, http://dx.doi.org/10.1016/j.msea.2003.11.034.

4. Eyre T S, Scott D. Wear Resistance of Metals. Akademic Pres, New York, 1977.

5. Gierak A. Tribologic wear. Publishing House of the Silesian University of Technology, Gliwice, 2005.

6. Grinis L, Haslavsky V, Tzadka U. Self-excited vibration in hydraulic ball check valve. World Academy of Science Engineering and Technology 2012; 6: 1041-1046.

7. Grybaxis R. Flow caused structural vibrations. Publishing House of the Silesian University of Technology, Gliwice, 2004.

8. Harris C M, Piersol A G. Shock and Vibration Handbook. McGraw-Hill, New York, 2002.

9. Ijas M, Virvalo T. Damping of low frequency pressure oscillation. Tampere University of Technology, Tampere, 2007.

10. Johnson K L. Mechanics of adhesion. Tribology Int. 1998; 31: 413-418, http://dx.doi.org/10.1016/S0301-679X(98)00060-7.

11. Крагельский И В, Михин Н М. О влиянии природы твердых тел на внешнее трение и о соотношении между адгрезионной и объемной составляющими. Теория трения износа. Наука 1965: 30-34.

12. Лозовский В Н. Диагностика авиационных топливных и гидравлических агрегатов. Транспорт, Москва,1979.

13. Markov D, Kelly D. Mechanism of adhesion-initiated catastrophic wear: pure sliding. Wear 2000; 239: 189-210, http://dx.doi.org/10.1016/ S0043-1648(99)00373-7.

14. Nosal S. Tribology. Introduction to the concepts of adhesion, wear and lubrication. Publisher Poznan University of Technology. Poznań, 2012.

15. Nosal S. Forming resistance to adhesive seizing with the use of selected models. Tribology 2015; 3: 121-135.

16. Nosal S, Wojciechowski $Ł$. Application of free surface energy measurements to assess resistance to adhesive seizing. Eksploatacja $\mathrm{i}$ Niezawodnosc - Maintenance and Reliability 2010; 45(1/2010): 83-90.

17. Panda L N, Kac R C. Nonlinear dynamics of a pipe conveying pulsating fluid with combination, principal parametric and internal resonances. Journal of Sound and Vibration 2008; 309: 375-406, http://dx.doi.org/10.1016/j.jsv.2007.05.023.

18. Sadowski J. Metal surfaces adhesive seizing criterion. Scientific Problems of Machines Operation and Maintenance 1980; 3: 247-263.

19. Stosiak M. Vibration insulation of hydraulic system control components. Archives of Civil and Mechanical Engineering 2011; 11(2):112117, http://dx.doi.org/10.1016/s1644-9665(12)60186-1.

20. Stosiak M. Identification of the impact of vibrations and the method of their mitigation at selected hydraulic valves. Publisher Wroclaw University of Technology, Wrocław, 2015.

21. Ułanowicz L. Studying destructive processes in air hydraulic drives, in terms of their sustainability. Publishing House of the Air Force Institute of Technology, Warszawa, 2013. 
22. Ułanowicz L. Wear processes of hydraulic plunger and barrel assemblies connected with the time of their work. Journal of Kones 2014; 21(4): 515-524, http://dx.doi.org/10.5604/12314005.1130517.

23. Zieja M, Ważny M. A model for service life control of selected device systems. Polish Maritime Research 2014; 21(2): 45-49, http://dx.doi. org/10.2478/pomr-2014-0018.

24. Zieja M, Ważny M, Stępień S. Distribution determination of time of exceeding permissible condition as used to determine lifetimes of selected aeronautical devices/systems. Eksploatacja i Niezawodnosc - Maintenance and Reliability 2016; 18(1): 57-64, http://dx.doi.org/10.17531/ ein.2016.1.8.

Leszek UŁANOWICZ

Air Force Institute of Technology

ul. Księcia Bolesława 6, 01-494 Warsaw, Poland

E-mail: leszek.ulanowicz@itwl.pl 